\title{
Preservice Teachers' Mentorship Experiences during Teaching Practice in a South African Teacher Preparation Program
}

\author{
Thuthukile Jita ${ }^{1} \&$ Paul Nwati Munje \\ ${ }^{1}$ School of Education Studies, Faculty of Education, University of the Free State, South Africa \\ Correspondence: Thuthukile Jita, School of Education Studies, Faculty of Education, University of the Free State, \\ South Africa.
}

Received: June 10, 2021

Accepted: August 13, 2021

Online Published: August 17, 2021

doi:10.5430/ijhe.v11n1p140

URL: https://doi.org/10.5430/ijhe.v11n1p140

\begin{abstract}
Mentor teachers are instrumental in teacher preparation programs during the teaching practice of preservice teachers that involves mentor-mentee relationships. This qualitative paper reports on the mentoring experiences of preservice teachers during eight weeks of teaching practice in 2020 using Gibbs' experimental learning as a conceptual framework. Forty-five preservice teachers participated in a reflective exercise, sharing their stories through reflective essays guided by open-ended questions. A thematic approach was used in data analysis. Findings indicated that mentors' experiences and personal characteristics, and abilities to create opportunities for growth influenced the preservice teachers' experiences during teaching practice. The mentees' perceptions toward mentor-mentee relationships also influenced their experience. Based on the findings, it is important to upskill mentors to equip them with professional and mentorship ethics to enable preservice teachers to acquire the requisite skills that will better prepare them as future professional teachers. The findings of this study can be useful in the process of developing professional development of mentors prior to teaching practice.
\end{abstract}

Keywords: mentorship, preservice teachers, teacher preparation program, teaching practice, reflective framework, South Africa

\section{Introduction}

Teaching practice is fundamental in developing preservice teachers' expertise as aspiring professionals (Mena, Hennissen, \& Loughran, 2017), a process best achieved through mentoring. Mentoring assists with the acquisition of relevant skills (Al-Jaro, Asmawi, \& Khaleel Mohammed Abdul-Ghafour, 2020). Mentorship is a complex terrain (Leshem, 2012). To ensure effective mentorship with valuable experiences during teaching practice, constant attention and adjustments are needed (Hudson \& Hudson, 2010; Maphalala, 2013). Therefore, mentors in placement schools need to possess relevant skills to adequately support preservice teachers in their endeavors (Orland-Barak \& Wang, 2020). As such, Mena et al. (2017, p. 58) suggested that teacher preparation institutions should “... not only pay more serious attention to the skills mentors use in their supervisory practice but also the extent to which their support facilitates the acquisition of knowledge". This raises the question whether mentors are equipped with the necessary skills or whether they simply learn on the job. If the response is the latter, then it justifies why the outcomes of mentor-mentee relationships are non-linear and cannot be predetermined. However, complexities, including individual mentor's attributes and mentees' capabilities, cannot be ignored. Wang (2001) highlighted the importance of context and mentors' beliefs. Ó Gallchóir, O'Flaherty, and Hinchion (2019), from an Irish perspective, demonstrated the role context plays in defining preservice teachers' experiences and identities as professional teachers. Hoben (2021) asserted that some preservice teachers lack the passion for teaching and become a burden to mentors, who are obliged to assist them to become professional teachers. This results in implications on their relationships.

Hagenauer, Waber, and De Zordo (2021, p. 1) argued that "the quality of the relationship between the mentor teacher and the student teacher is crucial for successful training". However, Hudson (2016) maintained that a positive mentor-mentee relationship is more likely to develop in a milieu where trust and respect exist. Hagenauer et al. (2021) supposed that when preservice teachers are warmly received and supported by their mentors, their confidence is boosted as they feel valued and motivated. Sokhulu (2018) argued that potential positive relationships are demonstrated from the way mentors initially react toward preservice teachers when introduced to them as mentees. 
Quality mentor-mentee relationships pave the way for preservice teachers to develop their identities and teaching practice as professional teachers (Hudson, 2016; Izadinia, 2018).

Mentors' lack of time to focus on their primary duty of teaching affects their ability to properly assist preservice teachers during teaching practice. In some instances, mentors are cautious not to focus on preservice teachers' needs at the detriment of completing the syllabus. Also common is the frustration of mentoring preservice teachers who lack content knowledge and other fundamental qualities (Hoben, 2021). This is exacerbated by the fact that some mentors are not professionally prepared for mentorship roles (Hoben, 2021). This creates avenues for insufficient mentee support, what Al-Jaro et al. (2020) suggested is endemic, with negative repercussions on preservice teachers' pedagogical practices.

It is therefore not uncommon for mentors to abscond their duties, abandoning all responsibilities to mentees, whom they consider as a relief and erroneously as their replacement in the classroom (Sokhulu, 2018). Preservice teachers with little experience are thrown into the deep end, resulting in the negative experiences emanating from teaching practice. Moosa and Rembach (2020) claimed that preservice teachers exposed to negative mentor-mentee engagements feel disempowered and unsupported in their learning journey. Mukeredzi, Mthiyane, and Bertram (2015) suggested mentor training and partnerships between all stakeholders involved, including universities, to ensure positive mentoring experiences for preservice teachers.

Positive teaching-practice experiences are attainable when preservice teachers receive quality guidance that empowers them with requisite skills. Guidance is easily attainable when relevant feedback is provided. Rauduvaite, Lasauskiene, and Barkauskaite (2015) supported the notion that feedback instils confidence and motivation in preservice teachers. This is because preservice teachers are opportune to access their own activities, identify positives and negatives and ameliorate them, and forge cooperation between themselves and their mentors. Mentors who set aside time to provide feedback and debriefings after sessions are instrumental in mentee professional development (Hagenauer et al., 2021). The Integrated Strategic Policy Framework for Teacher Education and Development (ISPFTED) in South Africa, 2011 - 2025 emphasized the importance of preparing future teachers with required skills to increase access to quality education and development opportunities (DBE/DHET 2011). Therefore, it is important for preservice teachers to get an opportunity to develop adequate skills mostly from teaching-practice mentoring experience as required by South African national curricula.

Mukeredzi (2017, p. 8), however, reasoned that feedback depends on how it is communicated because "[i]t is not what is said which hurts but how it is said". To ensure that developmental feedback is provided, mentors should engage in professional opportunities that guide them on non-judgmental feedback (McGraw \& Davis, 2017). This is important because feedback serves as a learning curve for preservice teachers and a useful tool for mentors to create a space for reflection, collaboration, and peer learning since errors and challenges are identified and ameliorated in the process (Mukeredzi, 2017; Rauduvaite et al., 2015). The different mentoring dynamics make it impossible to obtain similar narratives on teaching-practice experiences from preservice teachers placed under different mentors in different school contexts. This paper thus pursues the following question: What are preservice teachers' mentorship experiences during teaching practice in a South African teacher preparation program?

\section{Conceptual Framework}

This paper focuses on the mentorship experiences of preservice teachers, thus necessitating the use of a reflective framework. Gibbs' experimental learning is used as conceptual framework in this paper. This framework provides preservice teachers with the opportunity to reflect on their mentorship experiences during teaching practice in a more intense manner from their own perspective guided by open-ended questions. This derives from the fact that open-ended questions do not limit what to reflect on but allows for a narrative on every aspect of mentorship. The ideology of Gibbs originated from the experimental cycle initiated by David A. Kolb in 1988 (Gibbs, 1988). The framework has been used across a multitude of disciplines, including sports, education, and health. The approach of presenting their mentorship experiences in the form of an essay allows preservice teachers to share their experiences in their own words and as expansively as possible. This explains why research participants were able to share negative and positive mentorship experiences as well as lessons learned during teaching practice.

The framework is premised on the assumption that learning opportunities are relevant if experiences are shared, since mentorship constitutes an important component of teacher preparation (Shanks et al., 2020; Hagenauer et al., 2021). In the process, individual participants have the space to share their thoughts and feelings and, in some instances, make known what can be done to ameliorate existent challenges. Gibbs $(1988$, p. 11) noted that experimental learning deals with "... personal development and human potential and growth movement". Considering that school placement introduces a multitude of contextual factors, providing a space for preservice teachers to share their 
mentorship experiences from different schools gives rise to a broader picture of mentorship dynamics across the country. The reflective approach can be used by mentors and mentees (Sharman, 2013) and the outcomes may have policy implications for mentorship.

The sharing of mentorship experiences enables preservice teachers to recount lessons learned from mentors, challenges encountered, and instances of innovation in their journey to becoming professional teachers. Such an avenue, in the view of Gibbs, adds value to their professional lives. When preservice teachers reflect on their mentorship experiences, they understand themselves (Paterson \& Chapman, 2013), the complexities of the profession (Ditchburn, 2015; Ismail \& Çavuşoğlu, 2017), and insights that have the potential to better prepare them as future mentors. The process enhances their ability to become more active rather than passive learners (Mazzola, 2019). This paper thus zooms in to preservice teachers' mentorship experiences during teaching practice in a South African teacher preparation program.

\section{Method}

This qualitative study focuses on the mentorship experiences of preservice teachers during teaching practice in a South African teacher preparation program. Forty-five preservice teachers participated in a reflective exercise by sharing their mentorship experiences through essays guided by open-ended questions. The practice of analyzing preservice teachers' written reflections to understand their teaching-practice experiences is not new (Rauduvaite et al., 2015). This paper is part of a bigger project aimed at understanding the teaching-practice experiences of 113 preservice teachers in a post-graduate certificate in education (PGCE) program in 2020.

Data analysis occurred in two phases. Phase one involved the sorting of the larger data set involving a sample of 113 preservice teachers to identify emerging themes (Guest, Namey, \& Chen, 2020) that relate to mentorship experiences. From this process, 45 participants were identified who had provided information on mentorship experiences. All the participants (100\%) were South Africans and university graduates with at a bachelor's degree from different fields, such as science and humanities. All participants had no formal teaching qualification, hence studying PGCE, but some had already been practicing for this qualification as part-time students. Table 1 below presents the analysis of the background information on the four demographic variables, namely gender, age range, race and area where the teaching-practice school was situated.

Table 2. Frequency distribution of demographic information $(\mathrm{N}=45)$

\begin{tabular}{llll}
\hline Variable & Category & N (45) & $(\%)$ \\
\hline Gender & Female & 27 & 60.0 \\
& Male & 17 & 37.8 \\
Age range & Prefer not to say & 1 & 2.2 \\
& $21-26$ & 21 & 46.7 \\
& $27-32$ & 19 & 42.2 \\
Race & 33 and above & 5 & 11.1 \\
& African (black) & 22 & 48.9 \\
& Coloured (mixed race) & 15 & 33.3 \\
Area where teaching & Suburban & 8 & 17.7 \\
practice school was & Urban & 11 & 22 \\
situated & Rural & 19 & 24.4 \\
& & 15 & 33.3 \\
\hline
\end{tabular}

The frequencies of the control variables in Table 1 reflect the profile data of the participants registered for teaching practice, with more females $(60 \%)$ than males $(37.8 \%)$ enrolled for this qualification. Most of the participants $(\mathrm{n}=40$; $88.9 \%)$ were aged between 21 and 32 and the majority of participants were African $(n=22 ; 48.9 \%)$. These findings were not surprising as Davids and Waghid (2020) indicated that the majority of those enrolled for PGCE qualifications in South Africa are females, those of a younger age and black individuals.

In stage two, the data on the mentorship experiences from the 45 participants were arranged into relevant themes. Four themes emerged from this process: (i) mentor teachers' teaching experience and personal characteristics, (ii) preservice teachers' positive perceptions regarding mentor-mentee relationships, (iii) opportunities for growth provided by mentors, and (iv) negative mentor-mentee relationships. 
Permission to conduct the research was obtained from the university's ethical clearance committee and participating preservice teachers were duly informed of how the data obtained from the research would be utilized. They were also informed of their rights to confidentiality. As such, codes are used for participants' identification, replacing their real names. Participants are assigned the letter $\mathrm{P}$ with a number from 1 to 45 .

\section{Findings and Discussion}

The paper aimed at exploring preservice teachers' mentorship experiences during teaching practice in a South African teacher preparation program using a qualitative approach and a thematic method for data analysis. Findings indicate that different factors influenced the participants' mentorship experiences. For example, P20 described their mentorship experiences as "mixed baggage": "I have encountered a lot of challenges and many celebrations, and so much that I have learned." P38 agreed: "I worked with teachers that taught me more than I could have ever wished ... and then those who just left me to figure it out by myself." It is not uncommon for mentors to give limited mentorship (Mukeredzi et al., 2015), many wrongly considering the mentees' presence either as a sign of relief or a replacement. The data were thus categorized into the four main themes based on participants' varied voices. Each theme will be discussed next.

\subsection{Mentor Teachers' Teaching Experience and Personal Characteristics}

Participants aligned their teaching-practice experiences with mentor teachers' individual teaching experience and characteristics. For instance, P15 said: "My mentor teacher ... took on the role of guiding me through the schooling system she has been part of for more than 10 years." Similarly, P44 illuminated: "As a teacher with almost 30 years of experience, she has some of the most admirable qualities that I strive to develop as well." Furthermore, P38 explicated the relevancy of mentors' teaching experience and demonstrated the advantages thereof for preservice teachers, learners, and parents:

[My] mentor ... is so incredibly experienced in the field and has done all she can to try and help me succeed ... I learnt more from her ... not only because of her experience but because she wanted to help and mentor me. She showed me everything she could possibly think of; this included her portfolios, her way of planning ... how she teaches ... [and] assist the learners ... how to correctly use a rubric ..., so that if a learner or parent queries the marks ... you have a paper trail [to show] why their marks are what they are.

P38's disclosure aligns with the findings of Naidoo and Wagner (2020), who interrogated the extent to which mentors within the Australian context shape preservice teachers to become successful professionals in disadvantaged school communities. It can therefore be deduced that preservice teachers are likely to accumulate a multitude of skills if mentored by an experienced teacher, as seen in the next excerpt:

My History mentor teacher ... provided me with the ultimate experience of being a History teacher by teaching me how to mark learners' scripts ... I was given the opportunity to invigilate ... My Life Orientation mentor teacher ... provided me with similar opportunities, so that I may understand what it entails being a Life Orientation teacher. (P42)

P1 argued, however, that irrespective of a mentor teacher's teaching experience, preservice teachers need to be openminded and flexible to fully benefit from opportunities provided:

I have also learned how important it is to accept that we are not perfect teachers, and neither are our mentor teachers. We all have things to learn ... teaching experience has taught me how to learn from my mistakes ... I learned something from my mentor teacher and from the learners almost every day, and being open to this ... allowed me to grow, adapt, and think on my feet ...

In the same light, P45 argued that positive mentorship experiences are more probable when one is "under the guidance of an experienced teacher who can direct you along and help you become the type of teacher you want to be ... [and] [i]f you welcome the challenge, the experience will teach you a lot".

Apart from teaching experience, teacher age contributed to influencing the mentorship experiences of some participants as they tapped into the wisdom of their mentors (Mukeredzi, 2017). P9 maintained that age can potentially determine the path of a mentor-mentee relationship during teaching practice:

I really learnt a lot ... my mentor teachers were two different [ages] and ... each one has brought a different experience to the table. One is older and has been teaching for many years ... while the other one is young and has only been teaching for some few years ... this worked to my advantage ... I experienced two very different teaching practices, approaches and methods ... [I] easily understood and 
related to the teaching approach of my younger mentor because we both learned more or less the same values and qualities ... we both did not agree in promoting corporal punishment [but the] experienced mentor believes that it is necessary.

Furthermore, P8 said:

My Life Science mentor is in the same age group as me, and from day one she was very friendly and so welcoming. It was so easy to work with her as a mentor because she took me step by step and guided me slowly but surely on everything. She is very approachable about everything, and the learners even made a remark that I have adopted her teaching style, which is what they prefer.

The multitudes of views provided by participants confirm that mentorship experiences are not linear but varied and unique and can either be positive or negative. This is especially relevant when one considers P12's statement: "I was fortunate to have different mentor teachers for different modules. I saw a lot of ways to do things. The ways I liked I took with me, but the ways I did not like I left behind." The revelations from P8 and P12 demonstrate the development of teacher identity and teaching practices from mentorship experiences (Hudson, 2016; Izadinia, 2018; Yuan, 2016). This also emphasizes the importance of quality mentor-mentee relationships during teaching practice.

\subsection{Preservice Teachers' Positive Perceptions Regarding Mentor-Mentee Relationships}

Positive mentor-mentee relationships are critical in creating comfortable spaces for preservice teachers, with the probability of them achieving the requisite skills. Participating preservice teachers expressed varied perceptions about their mentor-mentee relationships which shaped their stay and achievements at the various schools. Positive relationships were determined somewhat from the kind of reception accorded to the participants. Regarding this, P22 recounted: "I was relieved [when] ... the Physical Science teacher arrived, and they introduced me to her ... [From] the reaction I got from her ... I knew ... that I am in good hands ... the best mentor teacher I had ...." This is consistent with the findings of Sokhulu (2018). Similarly, P11 said: "From the very first moment I walked into my mentor's class, I felt so welcome. I could immediately relate to her cheerful personality and warm heart." When preservice teachers receive a warm welcome in their school placement, they feel valued and accepted in the school community (Hagenauer et al., 2021; Rauduvaite et al., 2015). Such feelings have repercussions for their teaching practice going forward.

Receptive mentors are more likely to provide relevant assistance to mentees. In agreement with Yuan's (2016) findings, P31 commented: "Most teachers were very welcoming and offered their assistance if there was anything I needed clarity or help on." P6 concurred: “... my mentor teacher ... was extremely welcoming and warm. The rest of the staff were friendly and welcoming as well. They help[ed] guide me throughout these two months." Similarly, P7 explicated:

I spent almost the whole day with him, going through the school structure, classes and familiarizing myself with the timetable. During this time, I made notes and I was assisted with the school's timetable. I spent my day observing as many lessons as possible to get used to the idea of being with the learners.

Through observation, participants were able to learn from their mentors, as P36 echoed: "I learned valuable lessons from observing her and speaking ... about her teaching experiences throughout her career." In agreement, P3 clarified: "I have learnt a lot ... watching my mentor teachers teach." Similar sentiments emerged from P10: "[I learnt from] my mentor [how he] conducted his lessons ... manages his classroom ... resolves conflicts ... interact with the learners and get them to participate in the lesson." In the view of Sokhulu (2018), observations constitute an important part of teaching practice that should guide student teachers in shaping certain skills, an aspect which fulfils the essence of teaching practice in many respects. In the same vein, P39 said:

I attended classes with my mentor teachers for observation and [developed] ... passion in their work [and] ... differences in teaching style/approaches. While observing, at the back of my head, I kept on asking myself "Will this work for me or not?" ... [They] allowed me to ask them questions whenever I needed clarity, and being a curious person ... I learned more than I anticipated.

This aligns with Hudson (2016, p. 41), who described a positive mentorship relationship as one that creates spaces for preservice teachers to be educated "... about desirable attributes and practices that they can draw upon ...." Expanding on the multitude of advantages that accrue from observing mentors in the classroom, P26 explained:

On the first week, I did nothing but observe both mentors ... it was a good idea to get used to the environment and learners ... this helped me a lot because I even knew learners' names and knew how they behaved in class ... [It gave] me time to prepare for lessons that I will be presenting in the 
following week.

Additionally, P34 said: "I took the first week of teaching practice observing both my mentor teachers ...", described by P40 as "inspirational":

Lesson observations were ... inspirational ... The manner in which my mentor teachers delivered their classes was very professional. [They] communicated with learners with so much respect and showed a lot of compassion when answering their questions ...

Participants' voices demonstrate the impact of quality mentorship on the development of preservice teachers' professional identity (Hudson, 2016; Izadinia, 2018). The confidence of mentees is boosted when mentors are receptive, welcoming, and supportive, and provide relevant guidance. P32 agreed with this sentiment: "The support ... received from my mentor teachers were impeccable; it ... gave me the day-to-day strength and confidence ... to keep progressing ...." This also aligns with P18's view: "The biggest and most important thing I learned is to be confident. In the beginning, I was a little timid of the learners ... my mentor teacher gave me the confidence I needed to keep progressing." P35 added: "I could not have asked for a better mentor. I felt the support from day one and [it] gave me the confidence I needed to keep going. I really learned a lot from my mentor teacher ...." P42 added: "From the first day, I was ... given advice and guided by the teachers and the general workers at school, and this gave me confidence that I needed in order to progress further." Similar sentiments were voiced by P29: "My Life Orientation mentor [taught me] never to underestimate learners, [to] never humiliate them and never to think less of a learner." Al-Jaro et al. (2020) confirmed this by stating that when preservice teachers receive relevant support during teaching practice, they are likely to develop relevant professional skills.

Mentors who acted as good role models assisted the participants in varied ways. P27 recounted: "My mentors took the time to show me how they go [about] planning a topic, and I gathered every valuable advice from them," a view shared with P25. Likewise, P7 clarified: "My mentor teachers were extremely helpful and ... pushed us to strive for better results each day. After every lesson, I received constructive criticism ... I learned a lot ... every day ... I challenged myself to be better than ... yesterday." This aligns with what P44 had to say:

[She] is always patient and caring towards the learners in her class. She has an outstanding work ethic and she shows respect towards the learners and her colleagues. Her organizational and planning skills taught me to always be prepared for the most unexpected scenario and to have extra Mathematics worksheets available for the learners that want to practice more examples.

Furthermore, P23 elaborated on the nature of support received:

They [mentor teachers] took their time to help me and taught me a lot I didn't know, from setting my own question paper and assessing it, which is something I've never done before, to the different ways I could get learners to respect me, which is something I struggled with.

Additionally, P30 and P9 acknowledged and appreciated mentors who despite the Covid-19 pandemic provided assistance to preservice teachers and learners alike:

Even though it was Covid-19, the mentors ... went out of their way to ensure that I meet all my requirements. (P30)

I was amazed at how well my mentor teachers worked under so much pressure. They really tried to utilize every moment they had with the learners because they had already missed so much time due to the pandemic and really could not afford to lose more time. (P9)

Consistent with the views of participants is that mentors who exhibit positive characteristics create opportunities for mentees to grow in their career (Walkington, Stewart, Hall, Ackley, \& Shanahan, 2020).

\subsection{Opportunities for Growth Provided by Mentors}

The fundamental role of mentor teachers is to guide preservice teachers to acquire relevant skills that prepare them as better teachers, a prospect easily achievable if opportunities for growth are created to enhance learning and experimentation during teaching practice. Some mentors create supportive environments for mentees, with positive outcomes. P42 explained: "My mentor teachers supported me throughout this journey ... Through my mentor teachers, I learnt what it means to be a teacher ...."

The supportive environment created in the view of P42 instils confidence in preservice teachers and makes it easy for them to settle down in a new school. P41 reasoned that mentors who are quick to create a supportive environment are knowledgeable about the potential challenges that mentees are likely to encounter and are determined to ensure that 
they amass maximum benefits during teaching practice. The participant remarked:

... the mentor teachers were nice and had patience with me as a new teacher. They gave me all the necessary information ... gave advice on things to avoid and [those] to practice [as a] qualified teacher. This gave me a green light on what to expect and how to deal with challenges ... in future. (P41)

Emanating from P41's remark is that mentors who create opportunities for growth are more likely to pay attention to detail when preservice teachers are placed under their care, what Hudson (2016) saw as critical because it paves the way for a positive career path as professional teachers. Similarly, P40 excitingly echoed experiences regarding positive mentor-mentee relationships:

[My mentor] brought me under her wing and took time to help me plan my lessons. She provided me with all the helpful resources, including discs and ... textbooks. She ... allowed me to use her projector after she saw that I was competent with computer[s] and other electronic gadgets.

In addition, P43 shared testimony of their mentors regularly checking whether the right thing was being done:

My mentor teachers always checked my lesson plans before I could go to class and teach ... [They] complimented me ... they welcomed me to go to their classes and ... also accompanied me to classes to present my lessons.

Mentors who pay attention to detail are likely to give honest, frank, and positive feedback that serves as a growth point for preservice teachers (Hagenauer et al., 2021), a view supported by Waring (2013). The acquisition of relevant skills through feedback was resounded by P13 and P6:

They were good role models, always encouraged me to strive for the best, with a lot of support and guidance ... their mentoring has led me to becoming a leader ... rather than just a good follower ... I also received constructive feedback that helped me to improve a lot on my teaching performances through lesson evaluations. (P13)

My mentor teacher gave me words of encouragement after the lesson ... I received feedback ... and lesson evaluations ... [which] ... helped me gain perspective in [terms of] which teaching method [to] use [and] improve my teaching skills ... [They] introduced me to ... administrative duties ... filing ... marking ... setting up assessment papers [and] ... break duty.

Although feedback is instrumental during teaching practice, good feedback is determined by the way in which it is communicated (Hudson, 2016; Mukeredzi, 2017). As such, professional development opportunities are needed to assist mentors to acquire relevant skills, including how to provide non-judgmental feedback (McGraw \& Davis, 2017).

Irrespective of the importance of providing mentors with professional development on non-judgmental feedback, those being mentored need to have an open mind receptive to criticisms and willing to transform negatives into positives for feedback to have maximum impact. P37 explicated:

One of the most important lessons that I learned was the importance of feedback. When observing me in action, she would notice things that I had not noticed before. Maybe I ... look at the floor too often or stand in one place the entire time. My mentor teacher would point out these things to me, so I can make the necessary changes to improve. I found that when I was ... willing to hear criticism, I saw greater improvements in my teaching and increase in my confidence.

The role of feedback in teacher preparation cannot be overemphasized (Leshem, 2012) as it creates room for reflection and self-direction. This aligns with P16 and P37, who shared potential benefits for mentees who pay attention and seek relevant advice:

My Life Science mentor ... was always hands on, collecting and using different material and resources to make it easy for his learners to understand his content clearly ... I realized how this got students intrigued and motivated ... (P16)

It was always helpful to have my mentor teacher review my lesson plans and advise me on things that I could do to improve my ideas to ensure that they were viable in the classroom ... I needed to find ways to improve my teaching skills. I was not afraid to ask my mentor teacher for advice. (P37)

Some participants were given free rein to enable them to acquire most of the skills by doing. Such testimonies were shared by $\mathrm{P} 4$ and $\mathrm{P} 32$ :

My mentor teachers gave me so many opportunities to teach their classes ... my Life Science mentor made me solely responsible for two classes. These two classes would become my priority for the entire 
teaching practice. My Mathematics mentor would often allow me to teach more than two classes a day ... [They] ensured I got as much experience as I possibly could ... I would also assist ... in marking assessments and formal tests. (P4)

[I learnt] ... professionalism and content [presentation] ... classroom routine, such as introducing a lesson effectively, delivering content to learners in order, allowing ... engagement with learners ..., and concluding lessons effectively. She also demonstrated effective marking, lesson evaluations and setting of classroom tests ... My mentor also set a good example in terms of professional dress, classroom behavior and management. (P32)

Hagenauer et al. (2021) maintained that when mentors give preservice teachers more responsibilities, it symbolizes trust in their capabilities, something which not only enhances learning but also strengthens mentor-mentee relationships.

P28 re-echoed this assertion by saying: "They both dedicated their time to ensure that I gain ... experience in the process ... [They] inspired and helped me translate the theory I acquired from university into practice ... After my lesson, we will both reflect on my performance." Arnesson and Albinsson (2017) concurred that such opportunities prepare student teachers for the world of work. Similarly, P21 supported this: "My Life Orientation mentor was more than happy to guide me on what to look out for when marking." Within this context, P17 recounted:

My mentor teacher gave me the opportunity to teach most times than doing admin work ... that helped sharpen my public-speaking skills and improved [me] a lot on the interaction ... with the learners ... [It gave] me the opportunity to understand how the learners prefer being taught ....

Mena et al. (2017) considered experiences such as P17's as distinct and rewarding considering that some mentors prefer a directive approach, which does not give preservice teachers the leverage to develop to their full potential. This explains why P15 was appreciative of opportunities provided by mentors:

My mentor teachers were highly supportive and understanding. I will forever be grateful for the knowledge, guidance, and skills they have equipped me with ... They taught me to value my relationships with my colleagues. I have learnt to appreciate criticisms ... and to incorporate it into my way of doing things.

In agreement, $\mathrm{P} 18$ revealed:

... support from the teachers really helped me grow ... it provided room for me ... to ask questions and ask for help where necessary ... It is through accepting help that we learn and grow ... sharing opinions and ideas with seasoned teachers really helped me ... [I can] adapt to every situation ... I learned to be adaptable and to think on my feet.

Wexler (2020) agreed that a mentor has the capability to transform a novice teacher either way. In line with this, P33 maintained that opportunities to grow varied based on mentors' individuality and approaches:

We were monitored and supported by our mentor teachers, but we had the opportunity to teach, facilitate, and engage with the different classes. I learned a lot of skills ... and had the chance to co-teach with them and ... helped them with their teaching [and] admin. [They] ... were open and approachable in their classes; they created a safe environment for the learners ....

Related to P33's experience was P19's encounter with a strict mentor with good intentions: "My mentor was very strict, but with time she made me understand why it was important for her to be that strict with me. She helped me grow not only as a teacher but as an individual as well." Apart from direct advising and guidance, some mentors created space for participants to be innovative:

She went out of her way to make me feel part of her class ... she was always available for constructive advice and assistance; she gave me the freedom to develop my teaching strategies and to use technology and creativity to present my lessons. (P44)

The multitudes of accounts are a testimony that mentor-mentee relationships are a fluid and non-linear process requiring mentors and mentees to adapt to their individual contexts (Leshem, 2012). Failure to adapt has negative repercussions for preservice teachers' pedagogical practices. Where adaption is lacking, other dynamics could interplay to enhance negative mentor-mentee relationships.

\subsection{Negative Mentor-Mentee Relationships}

Sokhulu (2018) noted that although positive comments about mentoring experiences often dominate 
post-teaching-practice reflections, there are always isolated negative sentiments influenced by unique factors mostly contextual in nature. Mukeredzi (2017) confirmed that even where positive experiences are overwhelming, it is normal to identify pockets of negative practices, which Yuan (2016) maintained negatively affects mentees. The negative attitudes portrayed by some mentors was interpreted by P24 as fueled by stereotypes built over the years toward preservice teachers, a view supported by Hagenauer et al. (2021):

My biggest challenge ... was being assigned to a mentor who from past experience adopted a theory that student teachers are lazy and will never work as hard as they did ... that student teachers are there to assist them rather than them helping student teachers become good teachers ... Learning anything was a challenge ... I had to find myself a teacher to observe ... they never stayed to observe me when teaching, so once again, I would have to organize with another teacher teaching the same subject to teach one of her classes once in a while so that she could evaluate me. (P24)

The question of preservice teachers' capabilities that contribute to shaping negative relationships during teaching practice has been highlighted by Hoben (2021). Yuan (2016) argued that such negative experiences can inhibit mentees' learning and growth. The voice of P24 is also consistent with Sokhulu (2018), who confirmed that preservice teachers who have issues with their mentors are likely to enlist the services of other teachers to assist them to fulfil the teaching-practice requirements.

In some instances, these negative sentiments are transformed into learning opportunities. Concerning this, P14 shared an encounter with a mentor teacher who was described as lazy but contributed to unveiling hidden potentials:

My mentor teacher was a bit unorganized in the beginning, but towards the middle of my teaching practice, I could see that she worked on herself and started organizing herself and came prepared. She is pregnant, so she was absent quite a few days, where I had to take control of the class all by myself, but there was always a teacher with me invigilating. This was where I saw that I can manage a classroom all by myself.

In agreement, P2 demonstrated how creativity became the watchword when their mentor teachers allocated them a lot of responsibility:

My mentor teachers were very lazy, in such a way that they left everything on me to be ... responsible for all the two subjects, for Mathematics from Grade 8 to 9 and Physical Sciences from Grade 10 to 12. In terms of Grade 12s, I will go extra mile and even organize extra revision classes to prepare them for the trial and final exams.

Al-Jaro et al. (2020) agreed with P14 and P2 that although negative mentor-mentee relationships can potentially hamper preservice teachers' pedagogical practices, it is not unusual to see these negatives being transformed into learning curves.

However, P5 argued that the negative experiences were influenced partly by Covid-19:

She (mentor teacher) was in contact with a person that tested positive for Covid-19, so no one knew that I was supposed be there for my TP (teaching practice) and no one knew where I am supposed to go ... My mentor is absent and now I was responsible for all of his classes.

From P5's view, every attempt to zoom in to the teaching-practice experiences should be cognizant of the existence of a multitude of factors that interplay to determine how events play out during teaching practice.

\section{Conclusions}

Research has shown that mentorship is fundamental in teacher preparation in ensuring that preservice teachers become better professional people. The study aimed at understanding preservice teachers' mentorship experiences during teaching practice. Consistent from the findings is that mentors' experience and personal characteristics, and abilities to create opportunities for growth influence teaching-practice experiences for preservice teachers. In addition, mentees' perceptions toward mentor-mentee relationships influence their own teaching-practice experiences. Based on the findings, it is important to upskill mentors to equip them with professional and mentorship ethics to enable preservice teachers to acquire the requisite skills that better prepare them as future professional teachers. Understanding the connection between mentors' capabilities and support received by preservice teachers may provide a basis to rethink the responsibilities of mentors and their roles in the development of preservice teachers' competence. Yuan (2016) argued that preservice teachers do not always get what they expect from mentoring during teaching practice. In line with Mena et al. (2017), it is also imperative for teacher preparation programs to engage with and understand the nature of skills mentor teachers possess, as ongoing professional 
development is necessary to keep them abreast with expectations set for preservice teachers by various universities. A collaborative approach to mentoring is encouraged. This allows mentors and teacher educators the opportunity to discuss in unison expectations before teaching practice and thereby understand the needs and challenges of mentors that need addressing prior to the exercise. A detox session after the process should focus on discussing successes and failures and mapping a way forward that helps in strengthening teacher preparation programs vis-à-vis both preservice teachers and mentors.

\section{References}

Al-Jaro, M. S., Asmawi, A., \& Khaleel Mohammed Abdul-Ghafour, A. Q. (2020). Supervisory support received by EFL student teachers during practicum: The missing link. International Journal of Language and Literary Studies, 2(4), 22-41. https://doi.org/10.36892/ijlls.v2i4.437

Arnesson, K., \& Albinsson, G. (2017). Mentorship: A pedagogical method for integration of theory and practice in higher education. Nordic Journal of Studies in Educational Policy, 3(3), 202-217. https://doi.org/10.1080/20020317.2017.1379346

Davids, N., \& Waghid, Y. (2020). Tracking five years of teacher education enrolment at a South African university: Implications for teacher education. South African Journal of Higher Education, 34(2), 1-16. https://doi.org/10.20853/34-2-4044

Department of Basic Education/Department of Higher Education and Training (DBE/DHET). (2011). Integrated Strategic Planning Framework for Teacher Education and Development in South Africa 2011-2025. Pretoria: DBE/DHET

Ditchburn, G. M. (2015). Remembering reflection in pre-service teachers' professional experience. Australian Journal of Teacher Education, 40(2), 94-111. https://doi.org/10.14221/ajte.2015v40n2.7

Guest, G., Namey, E., \& Chen, M. (2020). A simple method to assess and report thematic saturation in qualitative research. PLoS One, 15(5), 1-17. https://doi.org/10.1371/journal.pone.0232076

Gibbs, G. (1988). Learning by doing: A guide to teaching and learning methods. London: Further Education Unit.

Hagenauer, G., Waber, J., \& De Zordo, L. (2021). 'She never actually let you walk into a trap': Exploring relational turning point events in the mentor-mentee relationship in the practicum. Professional Development in Education, 1-14. https://doi.org/10.1080/19415257.2021.1876155

Hoben, N. (2021). Challenges for mentors in working with secondary school pre-service teachers. New Zealand Journal of Educational Studies, 1-23. https://doi.org/10.1007/s40841-021-00198-0

Hudson, P., \& Hudson, S. (2010). Mentor educators' understandings of mentoring pre-service primary teachers. The International Journal of Learning, 17(2), 157-170. https://doi.org/10.18848/1447-9494/CGP/v17i02/46894

Hudson, P. (2016). Forming the mentor-mentee relationship. Mentoring \& Tutoring: Partnership in Learning, 24(1), 30-43. https://doi.org/10.1080/13611267.2016.1163637

Ismail, A. M., \& Çavuşoğlu, Ç. (2017). Theory into practice: The content of pre-service teachers' reflections in North Cyprus. In I. Amzat \& N. Valdez (Eds.), Teacher empowerment toward professional development and practices (pp. 221-237). Singapore: Springer. https://doi.org/10.1007/978-981-10-4151-8_15

Izadinia, M. (2018). Mentor teachers: Contributions to the development of preservice teachers' identity. In P. A. Schutz, J. Hong \& D. C. Francis (Eds.), Research on teacher identity (pp. 109-119). Cham, CH: Springer Nature. https://doi.org/10.1007/978-3-319-93836-3_10

Leshem, S. (2012). The many faces of mentor-mentee relationships in a pre-service teacher education programme. Creative Education, 3(4), 413-421. https://doi.org/10.4236/ce.2012.34065

Maphalala, M. C. (2013). Understanding the role of mentor teachers during teaching practice session. International Journal of Educational Sciences, 5(2), 123-130. https://doi.org/10.1080/09751122.2013.11890069

Mazzola, C. (2019, March 9). Bridging the gaps between passive and active learning in higher education. Colette Blog. Retrieved May 25, 2021, from http://blog.cmaz.co.uk/post.php?id=26

McGraw, A., \& Davis, R. (2017). Mentoring for pre-service teachers and the use of inquiry-oriented feedback. International Journal of Mentoring and Coaching in Education, 6(1), 50-63. https://doi.org/10.1108/IJMCE-03-2016-0023

Mena, J., Hennissen, P., \& Loughran, J. (2017). Developing pre-service teachers' professional knowledge of teaching: 
The influence of mentoring. Teaching and Teacher Education, 66, 47-59. https://doi.org/10.1016/j.tate.2017.03.024

Moosa, M., \& Rembach, L. (2020). Encounters with mentor teachers: First-year students' experiences on teaching practice. Mentoring \& Tutoring: Partnership in Learning, 28(5), 536-555. https://doi.org/10.1080/13611267.2020.1859326

Mukeredzi, T. G. (2017). Mentoring in a cohort model of practicum: Mentors and preservice teachers' experiences in a rural South African school. Sage Open, 7(2), 1-15. https://doi.org/10.1177/2158244017709863

Mukeredzi, T. G., Mthiyane, N., \& Bertram, C. (2015). Becoming professionally qualified: The school-based mentoring experiences of part-time PGCE students. South African Journal of Education, 35(2), 1-11. https://doi.org/10.15700/saje.v35n2a1057

Naidoo, L., \& Wagner, S. (2020). Thriving, not just surviving: The impact of teacher mentors on pre-service teachers in disadvantaged school contexts. Teaching and Teacher Education, 96, 2-11. https://doi.org/10.1016/j.tate.2020.103185

Ó Gallchóir, C., O’Flaherty, J., \& Hinchion, C. (2019). My cooperating teacher and I: How pre-service teachers story mentorship during school placement. Journal of Education for Teaching, 45(4), 373-388. https://doi.org/10.1080/02607476.2019.1639258

Orland-Barak, L., \& Wang, J. (2020). Teacher mentoring in service of preservice teachers' learning to teach: Conceptual bases, characteristics, and challenges for teacher education reform. Journal of Teacher Education, 72(1), 86-99. https://doi.org/10.1177/0022487119894230

Paterson, C., \& Chapman, J. (2013). Enhancing skills of critical reflection to evidence learning in professional practice. Physical Therapy in Sport, 14(3), 133-138. https://doi.org/10.1016/j.ptsp.2013.03.004

Rauduvaite, A., Lasauskienè, J., \& Barkauskaite, M. (2015). Experience in teaching practice of pre-service teachers: Analysis of written reflections. Procedia - Social and Behavioral Sciences, 191, 1048-1053. https://doi.org/10.1016/j.sbspro.2015.04.526

Shanks, R., Attard Tonna, M., Krøjgaard, F., Paaske, K. A., Robson, D., \& Bjerkholt, E. (2020). A comparative study of mentoring for new teachers. Professional Development in Education, 1-15. https://doi.org/10.1080/19415257.2020.1744684

Sharman, A. (2013). Mentorship: A reflective journey of self-discovery. Journal of Paramedic Practice, 5(11), 649-651. https://doi.org/10.12968/jpar.2013.5.11.649

Sokhulu, L. H. (2018). Exploring pre-service teachers' experiences of mentoring during teaching practice (Master's dissertation). University of KwaZulu-Natal, Durban, South Africa.

Walkington, H., Stewart, K. A., Hall, E. E., Ackley, E., \& Shanahan, J. O. (2020). Salient practices of awardwinning undergraduate research mentors-balancing freedom and control to achieve excellence. Studies in Higher Education, 45(7), 1519-1532. https://doi.org/10.1080/03075079.2019.1637838

Wang, J. (2001). Contexts of mentoring and opportunities for learning to teach: A comparative study of mentoring practice. Teaching and Teacher Education, 17(1), 51-73. https://doi.org/10.1016/S0742-051X(00)00038-X

Waring, H. Z. (2013). Two mentor practices that generate teacher reflection without explicit solicitations: Some preliminary considerations. RELC Journal, 44(1), 103-119. https://doi.org/10.1177/0033688212473296

Wexler, L. J. (2020). 'I would be a completely different teacher if I had been with a different mentor': Ways in which educative mentoring matters as novices learn to teach. Professional Development in Education, 46(2), 211-228. https://doi.org/10.1080/19415257.2019.1573375

Yuan, E. R. (2016). The dark side of mentoring on pre-service language teachers' identity formation. Teaching and Teacher Education, 55, 188-197. https://doi.org/10.1016/j.tate.2016.01.012

\section{Copyrights}

Copyright for this article is retained by the author(s), with first publication rights granted to the journal.

This is an open-access article distributed under the terms and conditions of the Creative Commons Attribution license (http://creativecommons.org/licenses/by/4.0/). 